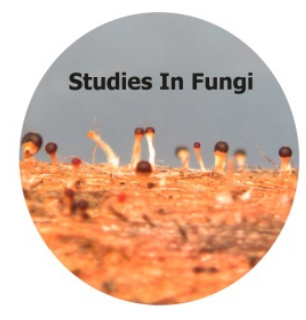

Studies in Fungi 4(1): 162-184 (2019) www.studiesinfungi.org ISSN 2465-4973

\title{
Article
}

Doi 10.5943/sif/4/1/19

\section{Phallales (Agaricomycetes, Fungi) from Southern Brazil}

\section{Trierveiler-Pereira $\mathbf{L}^{{ }^{*}}$, Meijer $\mathrm{AAR}^{2}$ and Silveira $\mathrm{RMB}^{1}$}

\author{
${ }^{1}$ Programa de Pós-Graduação em Botânica, Departamento de Botânica, IB, Universidade Federal do Rio Grande do \\ Sul (UFRGS), Porto Alegre - RS, Brazil. \\ ${ }^{2}$ Rodovia PR-405, km 36, Guaraqueçaba, Paraná, Brazil.
}

Trierveiler-Pereira L, Meijer AAR, Silveira RMB 2019 - Phallales (Agaricomycetes, Fungi) from Southern Brazil. Studies in Fungi 4(1), 162-184, Doi 10.5943/sif/4/1/19

\begin{abstract}
An illustrated and annotated checklist with key to 24 species of phalloids known to occur in Southern Brazil (States of Paraná, Santa Catarina and Rio Grande do Sul) are presented. The species belong to the orders Clathraceae, Claustulaceae, Lysuraceae, Phallaceae and Protophallaceae. Doubtful species are also discussed. Abrachium floriforme and Staheliomyces cinctus are the first reports from Southern Brazil and Laternea pusilla is new to the State of Santa Catarina.
\end{abstract}

Key words - Brazilian mycota - fungal taxonomy - phalloid fungi - Phallomycetidae - stinkhorns

\section{Introduction}

Members of Phallales (Phallomycetidae, Agaricomycetes) show great variability in size, shape and color. Some species, due to bizarre shape allied to bright colors, call the attention not only of mycologists, but also of people in general. Traditionally the order included species with expanded receptacle, commonly known as stinkhorns (e.g. species of Phallus Junius ex L. and Mutinus Fr.) or lattice stinkhorns (Clathrus P. Micheli ex L. spp.), but since the sequestrate genus Claustula K.M. Curtis (Cunningham 1931) was added to the order, many other truffle-like genera have been included, such as Protubera Möller, Gelopellis Zeller, Kjeldsenia W. Colgan et al., Phlebogaster Fogel, Trappea Castellano, and Gastrosporium Mattir. (Hosaka et al. 2006, Kirk et al. 2008, Trierveiler-Pereira et al. 2014b).

Although the Neotropical region has a high diversity of phalloids, with many rare and endemic species, the knowledge of the group in this area is still fragmentary. This fact can be attributed to several reasons, such as: ephemeral nature of the basidiomes, especially in tropical rainforests; lack of researchers familiarized with the species in the field; poor field notes of the collected specimens; difficulties in preserving specimens and therefore, badly preserved vouchers in herbaria; publications with poor descriptions and without accurate illustrations or photographs; usage of paleotropical or temperate species names to identify the neotropical species (Dring 1980).

In South America, the following larger surveys were dedicated to the group: Spegazzini 1886, Möller 1895, Rick 1929, Braun 1932, Wright 1949, 1960, Domínguez de Toledo 1995, Baseia et al. 2006, Cheype 2010, Magnago et al. 2013, Sandoval-Leiva et al. 2014, Maubet et al. 2018, Cabral et al. 2015, Lima et al. 2019, but many records and descriptions of new species have been published in mycological inventories (e.g. Rick 1906, 1961, Fischer 1933, Dennis 1970, Bononi et al. 1984, Lazo 2001, Meijer 2006, Cortez 2008, Trierveiler-Pereira et al. 2009b, Hernández Caffot et al. 
2013, Cabral et al. 2014) or in isolated publications (Domínguez de Toledo 1985, Baseia et al. 2003, Baseia \& Calonge 2005, Gómez \& Gazis 2006, Fazolino et al. 2010, Ottoni et al. 2010, Cortez et al. 2011a, Trierveiler-Pereira et al. 2009a, Trierveiler-Pereira \& Silveira 2012, Silva et al. 2015, Cortez \& Silva-Filho 2017, Crous et al. 2017, 2018).

Studies on the Phallales in southern Brazil are scarce; nevertheless more than 35 names of species have been reported from this region, including several new taxa (Möller 1895, Braun 1932, Trierveiler-Pereira et al. 2014c).

The aim of this study is to ascertain which phalloid species occur in the Southern Region of Brazil, based on field collections and examination of herbarium specimens. Doubtful species and records are discussed, and illustrations of all the species and a key as aid to identification are also presented.

\section{Materials \& Methods}

Southern Brazil includes the States of Paraná (PR), Santa Catarina (SC) and Rio Grande do Sul (RS), and covers $576,410 \mathrm{~km}^{2}$ (about $7 \%$ of the Brazilian territory). The climate is subtropical in almost the entire region, except the northeastern part of the region that is tropical. The annual average temperatures vary between $12^{\circ} \mathrm{C}\left(53.6^{\circ} \mathrm{F}\right)$ and $22^{\circ} \mathrm{C}\left(71.6^{\circ} \mathrm{F}\right)$.

The list of species presented here was compiled from fieldwork, herbaria exsiccates, and literature. Macro and microscopical analysis of the material followed traditional methods used to study gasteroid basidiomycetes (Miller \& Miller 1988). Brazilian specimens of L. pusilla are fully described, while for other species, one or more references are given to published descriptions. Color codes (e.g. 8A4) are based on Kornerup \& Wanscher (1978). Voucher material was deposited at ICN, HUCS, FLOR, and MBM (Thiers 2011).

The macroscopic illustrations were based on photographs taken in the field or dried specimens kept at herbaria. Illustrations are represented for all species, with the exception of $P$. callichrous, a species morphologically very similar to $P$. indusiatus, except for the color of the receptacle. Color photographs of many species herein discussed were presented by TrierveilerPereira (2015).

Species are listed alphabetically within each family according to the classification presented by Trierveiler-Pereira et al. (2014b): Clathraceae, Claustulaceae, Lysuraceae, Phallaceae and Protophallaceae. We also present a list of excluded and doubtful records.

\section{Results}

\section{Key to the species of Phallales occurring in Southern Brazil}

1. Mature basidiome globose to subglobose, not forming an expanded pseudostipe or receptacle (truffle-like)

1'. Mature basidiome with pseudostipe simple, ramified into arms, columns, or latticed receptacle

2. Basidiome hypogeous to subhypogeous, external surface yellowish brown; in longitudinal section can be observed a thick gelatinous matrix below the peridium; glebal mass globose surrounding a central columella, gleba not connected to the peridium

Gelopellis thaxteri 2'. Basidiome epigeous, external surface whitish, grayish yellow to light brown; in longitudinal section elongated elliptical glebal plates immersed in a gelatinous matrix can be observed; columella absent; glebal plates connected to the inner part of the peridium by sutures

Protubera maracuja

3. Basidiome with pseudostipe ramified into columns or latticed receptacle................................... 4

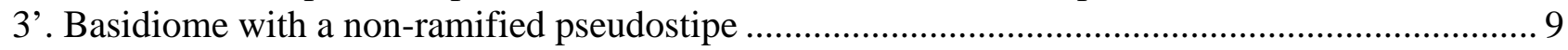

4. Pseudostipe ramified into $2-5$ columns fused at the apex ........................................................ 5

4'. Receptaculum latticed (clathroid), forming more or less polygonal meshes ............................... 8

5. Glebal mass spread in lateral projections ('teeth') of the columns ........................................... 6 
5'. Glebal mass confined to glebifers or spread along the inner side of the columns ....................... 7 6. Basidiome grayish yellow, pale yellow to pale orange, glebal mass distributed along the columns, columns robust

Blumenavia rhacodes 6'. Basidiome white, gleba confined to the upper quarter or one third of the columns, columns thin, fragile Blumenavia angolensis 7. Basidiome less than $4 \mathrm{~cm}$ high, bright red to pale pink, with crests along the margins; gleba confined to a single glebifer, suspended below the columns' junction

Laterna pusilla

7’. Basidiome larger, yellowish to orange, without crests along the margins; gleba spread along the inner side of the columns

Clathrus columnatus 8. Receptacle reddish, salmon to pale pink; meshes surrounded by a corrugated and folded membrane where glebal mass is spread. Clathrus crispus 8'. Receptacle white to pale yellow; no membrane surrounding the meshes; gleba confined to glebifers inside the receptacle.

Clathrus chrysomycelinus

9. Pseudostipe perforate, constricted by a ring at the upper part, glebal mass covering the ring

Staheliomyces cinctus

9'. Basidiome not as above

10. Glebal mass spread directly over the pseudostipe ............................................................ 11

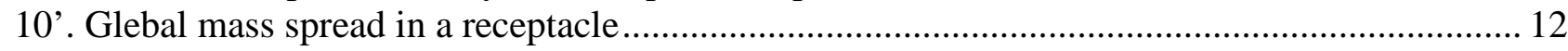

11. Fertile area delimited; surface of the pseudostipe rugulose; pseudostipe light pink and fertile area dark pink .....

Mutinus argentinus

11'. Fertile area not delimited; surface of the pseudostipe even; pseudostipe light orange and fertile area dark orange

Mutinus elegans

12. Pseudostipe surmounted by arms or with a flower-shaped receptacle ................................... 13

12'. Pesudostipe not as above.

13. Pseudostipe with a flower-shaped receptacle

Abrachium floriforme

13’. Pseudostipe surmounted by arms ....

14. Arms usually in a horizontal position, long and slender, smooth, attached to the margin of a flat disc across which the gleba is spread; basidiome with reddish color. Aseroë rubra 14'. Arms upright, short, thick, conical, transversally furrowed, attached to apex of the pseudostipe; basidiome whitish to yellowish 15

15. Basidiome less than $5 \mathrm{~cm}$ high; pseudostipe reduced; arms and pseudostipe both white

15’. Basidiomata larger; pseudostipe long; arms internally whitish, orange or reddish

Pseudocolus garcie

.Lysurus cruciatus

16. Gleba situated on a spherical, clathroid receptacle at the apex of the pseudostipe; receptacle yellowish, orange to reddish Lysurus sphaerocephalum

16'. Basidiome not as above.

17. Receptacle surface lamellate, with a white calyptra (membranous cap) at the apex; basidiome robust, about $15 \mathrm{~cm}$ high

Itajahya galericulata

17'. Basidiome not as above.

18. Receptacle spherical at first, then campanulate; outer volva tuberculate, inner volva yolk-yellow

Phallus glutinolens

18'. Receptacle campanulate to cylindrical; outer volva smooth, inner volva whitish or very pale .....

19. Indusium (veil) absent .

19'. Indusium (veil) present

20. Pseudostipe and receptacle reddish 21

20'. Pseudostipe and receptacle whitish

Phallus rubicundus

21. Indusium short, not covering the pseudostipe entirely Phallus campanulatus

21 '. Indusium long, covering the pseudostipe entirely... Phallus duplicatus

22. Receptacle surface rugulose, merulioid; with a white spongy expansion ('cap') on the top when recently exposed

.Phallus aureolatus 
22’. Receptacle surface reticulate-alveolate; ‘cap’ absent

23. Receptacle white

Phallus indusiatus

23’. Receptacle orange to pale pink.

Phallus callichrous

Taxonomy

Clathraceae

Abrachium floriforme (Baseia \& Calonge) Baseia \& T.S.Cabral, Mycotaxon 119: 424 (2012)

Figs 1A, 4A

三Aseroe floriformis Baseia \& Calonge, Mycotaxon 92: 170 (2005)

Description - Baseia \& Calonge (2005), Trierveiler-Pereira \& Baseia (2011), Magnago et al. (2013).

Distribution in Southern Brazil - SC (present study).

Material examined - BRAZIL, Santa Catarina, Santo Amaro da Imperatriz, Plaza Hotel Caldas da Imperatriz, on soil among litterfall, 30 Oct 2012, A.C. Magnago 452 (FLOR 47631).

Notes - the species is easily recognized in the field due to its characteristic sunflower-shaped receptacle. Pseudostipe and receptacle may show different shades of pink, yellow and orange. The glebal mass is spread over a reddish perforate disc in the center of the receptacle. The species is known from the Atlantic rainforest in Northeastern and Southeastern Brazil (Baseia \& Calonge 2005, Trierveiler-Pereira \& Baseia 2011, Magnago et al. 2013) and its occurrence in Southern Brazil is here reported for the first time.

Aseroë rubra Labill, Bull. Murith. Soc. Valais. Sci. Nat. 1: 145 (1800)

Fig. 1B

Description - Dring (1980).

Distribution in Southern Brazil - RS (Rick 1961, Guerrero \& Homrich 1999), PR (Meijer 2006).

Material examined - BRAZIL, Rio Grande do Sul, Salvador do Sul (= São Salvador), 1943, P. Hansen (PACA-FR 12206); São Francisco de Paula, Fazenda dos Novilhos, near Pinus, 28 Jan 2011, L.O. Rosa 513 (MIUCS 830).

Notes - In Southern Brazil the species is characterized by bright red color and receptacle formed by numerous long arms (up to 22). The glebal mass is spread over a central disc. Aserö̈ rubra is recorded from different parts of the world, including tropical and temperate areas, and much variability has been observed in the species, which justifies its long list of synonyms. Nevertheless, many names treated as synonym may correspond to independent taxa. In Southern Brazil, the species has been observed several times near Pinus, so it might indicate that it has been introduced.

Blumenavia angolensis (Welw. \& Curr.) Dring, Kew Bull. 35(1): 53 (1980)

Fig. 1C

Description - Dring (1980), Degreef et al. (2013), Trierveiler-Pereira et al. (2014c).

Distribution in Southern Brazil - PR (Meijer 2006), SC and RS (Trierveiler-Pereira et al. 2014c).

Material examined - BRAZIL, Paraná, Antonina, Reserva Natural do Rio Cachoeira, 17 Aug 2005, A.A.R. de Meijer 4339 (MBM); Santa Catarina, Florianópolis, Unidade de Conservação Desterro, 9 Nov 2013, A.C. Magnago 816 (FLOR 51619); Rio Grande do Sul, São Francisco de Paula, FLONA de São Francisco de Paula, 8 Feb 2014, C.R. Alves 143 (ICN 177268); ibid., 13 Apr 2014, A.C. Magnago 1049 (ICN 177269).

Notes - The species is characterized by a pure white receptacle formed by $3-5$ columns and a gleba confined to glebifers situated on lateral projections ('teeth) of the columns' margins. The fertile area corresponds to the upper quarter or third of the receptacle. Blumenavia angolensis has narrower columns than B. rhacodes, and according to Dring (1980), the tubular arrangement of the columns in transversal section is also different. In Brazil the species is known from the Southern 
and Southeastern regions (Meijer 2006, Dring 1980, Trierveiler-Pereira et al. 2014c). Ligiella, a new genus proposed from Costa Rica (Sáenz 1980), also has whitish receptacle and gleba restricted to the upper part of the basidiomata. According to Sáenz (1980) Ligiella differs from Blumenavia in having the gleba borne directly on the underside of the columns, instead of confined to glebifers; and having a clathroid receptacle instead of columns.

Blumenavia rhacodes Möller, Bot. Mitt. Trop. 7: 57 (1895)

Fig. 1D

Description - Dring (1980), López et al. (1981). Trierveiler-Pereira et al. (2014c).

Distribution in Southern Brazil - RS (Rick 1961, Trierveiler-Pereira et al. 2014c), SC (Möller 1895, Lloyd 1907a).

Material examined - BRAZIL, Rio Grande do Sul, Porto Alegre, Morro Santana, on rotten wood, 17 May 2011, L. Trierveiler-Pereira 230 (ICN); ibid, on rotten wood, 31 May 2011, L. Trierveiler-Pereira 247 (ICN); Porto Alegre, Campus da Universidade Federal do Rio Grande do Sul, 01 Apr 2014, E.P. Fazolino 164 (ICN 177266); ibid., 02 Apr 2014, E.P. Fazolino 165 (ICN 177267); São Leopoldo, J. Rick (PACA-FR 12549); ibid., 1906, J. Rick (PACA-FR 12550); ibid., 1907, J. Rick (PACA-FR 12552); ibid., 1932, J. Rick (PACA-FR 12551); ibid., J. Rick (PACA-FR 12553); ibid., 1929, B. Braun (PACA-FR 13857 - as Laternea pseudocrispa); ibid., 1930, J. Rick (PACA-FR 21358 - as Pseudocolus rugulosus).

Notes - the species is characterized by a pale orange to greyish orange (beige) receptacle consisting of 3-5 columns, and glebifers occuring on lateral expansions ("teeth") distributed along the column's margins. The species is found on forest soil and rotten wood and immature forms are usually dark. The color of the receptacle has been reported as orange fading to yellow or white (Dring 1980), but according to our own experience it is usually pale yellow (Trierveiler-Pereira et al. 2014c). The species is sometimes referred as Laternea rhacodes (Möller) Lloyd (Lloyd 1909, Rick 1929, 1961). Recent molecular studies have shown that $B$. rhacodes is phylogenetically very close to Laternea triscapa (Trierveiler-Pereira et al. 2014b). Blumenavia toribiotalpaensis VergasRodríguez, described from Mexico, was synonimized with B. rhacodes by Calonge et al. (2007).

Clathrus chrysomycelinus Möller, Bot. Mitt. Trop. 8: 22, 146 (1895)

Fig. 1E

Description - Möller (1895), Fazolino et al. (2010).

Distribution in Southern Brazil - RS (Rick 1961), SC (Möller 1895), PR (Meijer 2006).

Material examined - BRAZIL, Rio Grande do Sul, Pelotas, 1907, J. Rick (PACA-FR 12620, not well preserved); Dom Pedro de Alcântara, 15 May 2012, M.A. Reck 733/12 (ICN 175592); Paraná, Antonina, Reserva Natural Rio Cachoeira, 06 May 2006, C.L. Bandeira \& A.A.R. de Meijer 4345 (MBM); Paranaguá, Ilha do Mel, 03 Feb 1990, A.A.R. de Meijer 1472 (MBM); ibid., 03 June 1990, A.A.R. de Meijer 1797 (MBM).

Notes - The species is characterized by whitish, clathroid receptacle and gleba arranged in glebifers on the inner part of the receptacle. The lower meshes are usually more elongated then those at the apex. The branches of the receptacle are typically dorsiventrally compressed, wrinkled, and with a median longitudinal groove. Three collections are registered as C. chrysomycelinus at PACA, but two of them are badly damaged (FR 12631 and 12633), and the other one not seem to correspond to this species, since the gleba is not confined to glebifers and the meshes are robust.

A photograph of Ileodictyon cibarium from Northeastern Brazil (Baseia et al. 2006) depicts a young basidiome of $C$. chrysomycelinus - it is possible to see the internally situated glebifers, which do not occur in Ileodictyon, and dorsiventrally compressed meshes with a median longitudinal groove. Other whitish Clathrus species known to occur in tropical America (not considering whitish forms of usually colored species) are C. oahuensis and C. roseovolvatus (Lécuru et al. 2013); C. oahuensis presents setae on the lower meshes, and C. roseovolvatus has a pinkish to purple volva with the gleba not confined to glebifers. A specimen described from Paraguay (Maubet et al. 2018) had the fresh receptacle pale pink. 
Description - Magnago et al. (2013).

Distribution in Southern Brazil - RS (Guerrero \& Homrich 1999, Rick 1961, Sobestiansky 2005), PR (Meijer 2006).

Material examined - BRAZIL, Rio Grande do Sul, Santa Maria, Três Barras, 14 May 2010, L. Trierveiler-Pereira 39 (ICN); Viamão, Parque Estadual Itapuã, 18 Jun 2011, L. TrierveilerPereira 257 (ICN); São Leopoldo, 1930, J. Rick (PACA-FR 13858); ibid., 1929, B. Braun (PACAFR 13859); ibid., J. Rick (PACA-FR 13860); ibid., 1931, J. Rick (PACA-FR 13861); ibid., 1929, J. Rick (PACA-FR 13862); ibid., 1930, J. Rick (PACA-FR 13864); ibid., 1930, J. Rick (PACA-FR 13865); ibid., 1930, J. Rick (PACA-FR 13866); ibid., B. Braun (PACA-FR 13868); ibid., J. Rick (PACA-FR 13867 - as Laternea pusilla); Paraná, São José dos Pinhais, 18 Jun 2002, A.A.R. de Meijer s/n (MBM).

Notes -This species is characterized by the pale red to orange receptacle formed by 2-4 robust columns and glebal mass spread over the inner surface of the columns. The columns have a spongy consistence and usually they are dilacerate in the inner part. According to Rick (1929), it is a common species never found inside forests. The species occurs in lawns and pastures, as well as on sandy soil, sometimes near lagoons and along the ocean. Although there is no voucher of the species from Santa Catarina, the first author has seen specimens on sandy soil near the beach. Clathrus columnatus has also been reported as Linderiella and Laternea (Sobestiansky 2005, Meijer 2006, Rick 1929).

Clathrus crispus Turpin, Dict. Sci. Nat. Atlas Acotyl., Tab. 29 (1820)

Fig. 1G

Description - Lloyd (1909), Wright (1949), Dring (1980), Maubet et al. (2018).

Distribution in Southern Brazil - RS (Rick 1961).

Material examined - BRAZIL, Rio Grande do Sul, Santa Maria, Três Barras, 14 May 2010, L. Trierveiler-Pereira 39 (ICN); Viamão, Parque Estadual Itapuã, 18 Jun 2011, L. TrierveilerPereira 257 (ICN); São Leopoldo, 1930, J. Rick (PACA-FR 13858); ibid., 1929, B. Braun (PACAFR 13859); ibid., J. Rick (PACA-FR 13860); ibid., 1931, J. Rick (PACA-FR 13861); ibid., 1929, J. Rick (PACA-FR 13862); ibid., 1930, J. Rick (PACA-FR 13864); ibid., 1930, J. Rick (PACA-FR 13865); ibid., 1930, J. Rick (PACA-FR 13866); ibid., B. Braun (PACA-FR 13868); ibid., J. Rick (PACA-FR 13867 - as Laternea pusilla).

Notes - This species is characterized by the globose to sugblobose, salmon to reddish receptacle with more or less regular meshes, and the corrugated and folded membrane surrounding the meshes. Lloyd (1909) judges it to be common in the West Indies, from Mexico southward to Uruguay. The pale form, which was described as C. americanus Lloyd (Lloyd 1909) and later reduced to C. crispus var. americanus (Lloyd) J.E. Wright (Wright 1949), is treated as C. crispus by Dring (1980).

Clathrus crispus was also reported from Paraná (Meijer 2006), but now the author believes that his material could correspond to a different species. The voucher specimens (A.A.R.M. 1183 and A.A.R.M. 1899), both from the sea-coast of Paraná, are unavailable for us to study, since both collections were lent out to herbarium LG (Liège, Belgium) a quarter of a century ago.

Laternea pusilla Berk. \& M.A. Curtis, in Berk., J. Linn. Soc., Bot. 10: 343 (1868)

Figs $1 \mathrm{H}, 4 \mathrm{~B}$

Description - Unexpanded basidiome globose to sugblobose, 0.9-1.4 cm in diam., white (1A1), with long mycelial strands at the base, found on rotten wood. Expanded basidiome epigeous, up to $3.9 \mathrm{~cm}$ high. Volva $1.5 \mathrm{~cm}$ high $\times 1.4 \mathrm{~cm}$ in diam., sacculiform, externally white (1A1), internally with hyaline gelatinous content. Receptacle $2.7 \mathrm{~cm}$ high $\times 1.5 \mathrm{~cm}$ in diam., formed by $2-$ 3 arched columns; columns spongy, orange-red (8B6), pastel red (8A4) to dull red (8B3), with prominent crests at the column's margins (arising from the inner margins and projecting to the outer margins). Gleba mucilaginous, olive brown (4F8), confined to a single glebifer located under the connection point of the columns' apices; glebifer cordiform to star-shaped, hanging from the receptacle, $0.4 \mathrm{~cm} \times 0.35 \mathrm{~cm}$, orange red (8A8). Basidiospores 3-4 $\times 1-1.5 \mu \mathrm{m}$, cylindrical to ellipsoid, hyaline to greenish, smooth. 
Distribution in Southern Brazil - PR (Meijer 2006) and SC (present study).

Material examined - BRAZIL, Paraná, Campina Grande do Sul, Parque Estadual Pico Paraná, forest trail to Pico Paraná, 12 Feb 2011, A.A.R. de Meijer 4529 (MBM); Santa Catarina, Urubici, Morro da Igreja, 16 Feb 2013, C.H. Cabrera 66 (FLOR 47616); ibid., PARNA São Joaquim, Campus de Santa Bárbara, 02 Sep 2013, A.N.M. Furtado 318 (FLOR 50692).

Notes - L. pusilla is characterized by small-sized basidiomata (about 2.0-3.5 cm high), growing on rotten wood at high altitudes in the Neotropics; receptacle bright red fading with age, formed by 2-4 columns with prominent crests and bearing a single glebifer hanging from the apex (Sandoval-Leiva et al. 2014). Laternea pusilla is known from forests in Cuba, Jamaica, Guadaloupe, Nicaragua, Costa Rica, Mexico, Guyana, Chile and Brazil (Dring 1980, Sáenz 1975, Sáenz \& Nassar 1982, López et al. 1982, Meijer 2006, Sandoval-Leiva et al. 2014). Here we describe the Brazilian specimens for the first time. In southern Brazil the species occurs only in cloud forests above 1,000 m altitude. One specimen kept at PACA (FR 13867) identified as $L$. pusilla actually corresponds to a small specimen of $C$. columnatus.

Pseudocolus garciae (Möller) Lloyd, Mycol. Notes (Cincinnati) 28: 358 (1895)

Fig. 1I

Description - Möller (1895), Rick (1929), Dring (1980), Sulzbacher et al. (2013).

Distribution in Southern Brazil - RS (Rick 1961, Sulzbacher et al. 2013), SC (Möller 1895).

Material examined - BRAZIL, Rio Grande do Sul, São Leopoldo, 1905, J. Rick (PACA-FR 12816).

Notes - The species is characterized by whitish, small (about $2 \mathrm{~cm}$ high) basidiomata, formed by a short pseudostipe (1 cm high) surmounted by 3-4 arms tapering upwards and united at the tips. The glebal mass is spread over the inner portion of the arms. The other species currently recognized in the genus, $P$. fusiformis (E. Fisch.) Lloyd [according to Dring (1980) is the correct name for $P$. javanicus (Penz.) Lloyd and P. schellenbergiae (Sumstine) Johnson], has a reddish to orange basidiome and its distribution is restricted to Australasia. Records of P. fusiformis from U.S.A. probably concern introductions (Dring 1980). A specimen from Peru identified as $P$. fusiformis (Gómez \& Gazis 2006) is probably different from the Paleotropical species. One specimen reported as $P$. javanicus in Argentina (Wright 1960) probably corresponds to P. garciae, judging the receptacle color and basidiome size.

\section{Claustulaceae}

Gelopellis thaxteri (Zeller \& C.W. Dodge) Zeller, Mycologia 31(1): 22 (1939)

Fig. 2B

Description - Zeller \& Dodge (1929), Homrich (1969).

Distribution in Southern Brazil - RS (Zeller \& Dodge 1929, Homrich 1969).

Material examined - BRAZIL, Rio Grande do Sul, Porto Alegre, near a small clump of native bamboo, 28 Apr 1970, M.H. Homrich 381 (ICN 6052).

Notes - The species is characterized by the hypogeous to subhypogeous habit; globose to sugblobose basidiomata (up to $3.5 \mathrm{~cm}$ in diam.), and pluristratified, thick peridium (1-3 mm thick). In transversal section can be seen the olive gray glebal mass immersed in a gelatinous matrix and a central cylindrical, unbranched columella. The columella has a spongy consistence that resembles the pseudostipe of a Phallus species (Homrich 1969). The gelatinous layer situated under the peridium is continuous, i.e. it is not interrupted by any cavities (as in Hysterangium) or sutures (as in Protubera).

Basidiospores are 3-4 $\mu \mathrm{m}$ long, which differentiates it from G. macrospora (basidiospores 7$14 \mu \mathrm{m}$ long), a macroscopically similar species described from Chile (Zeller 1939). The examined specimen is very poorly preserved and the only structure left is the thick peridium. Microscopically, it was possible to observe basidiospores and the pluristratified peridial layer typically composed of filamentous hyphae with large clamp connections. Other voucher specimens reported by Homrich (1969) could not be traced by us. Currently six species are recognized in the genus (Kirk et al. 2008), of which G. thaxteri is the only one reported from Brazil. 


\section{Lysuraceae}

Lysurus cruciatus (Lepr. \& Mont.) Henn., Beibl. Hedwigia 41: 172 (1902)

Fig. 2C

Description - Dring (1980), Cortez et al. (2011b), Sandoval-Leiva et al. (2014)

Distribution in Southern Brazil - RS (Rick 1961, Cortez et al. 2011b, Trierveiler-Pereira et al. 2018), PR (Meijer 2006).

Material examined - Lysurus cruciatus var. cruciatus: BRAZIL, Rio Grande do Sul, Pinheiro Machado, 13 Sep 2008, M. Molz (ICN 154342); Porto Alegre, Apr 2009, M.G. Rossoni (ICN 154345); São Gabriel, Fazenda Cambará, 08 Jul 2012, L.P. Honaizer 41 (ICN 175590); São Leopoldo, 1929, B. Braun (PACA-FR 14003); ibid., B. Braun (PACA-FR 14005); ibid., 1929, J. Rick (PACA-FR 14017); ibid., B. Braun (PACA-FR 19701); Salvador do Sul [= São Salvador], 1943, J. Rick (PACA-FR 20227); Paraná, Santa Mariana, Fazenda Palmeira, 31 Mar 1998, A.A.R. de Meijer 3560 (MBM). Lysurus cruciatus var. nanus: BRAZIL, Rio Grande do Sul, Dom Pedro de Alcântara, Cova Funda, Dec 2007, leg. M.A. Reck (ICN 154343); Torres, Lagoa Itapeva, 27 Apr 2007, leg. M.A. Reck (ICN 154344); São Leopoldo, B. Braun (PACA-FR 14004); ibid., B. Braun (PACA-FR 14008).

Notes - L. cruciatus is a widespread species, characterized by a whitish pseudostipe surmounted by $5-8$, reddish to white arms. These arms are usually united at the tip, but they can become detached as the basidiome matures. This species used to be confused with the Asian and African L. gardneri Berkeley, but the latter differs in having the arms with a sterile base and villose fertile parts [as illustrated by Dring (1980) and Dissing \& Lange (1963)]. Lysurus cruciatus var. nanus Calonge \& B. Marcos, characterized by smaller basidiomata and orange yellow arms, was reported from Southern Brazil by Cortez et al. (2011b). Molecular data showed that there is no significant difference between this variety and the typical one (Martín et al. 2005). Lysurus arachnoideus (E. Fisch.) Trierv.-Per. \& K. Hosaka was reported from the Brazilian Amazon (Cabral et al. 2015) and it was also photographed in Southern Brazil (Florianópolis, Santa Catarina) in a lawn (Fig. 4F). Unfortunately, the voucher specimens was not available for examination.

Lysurus sphaerocephalum (Schltdl.) Hern. Caff., Urcelay, Hosaka \& L.S. Domínguez, Mycologia pag (2018)

Fig. 2D

Description - Hernández Caffot et al. (2018), Cortez et al. (2011b).

Distribution in Southern Brazil - RS (Rick 1961, Cortez et al. 2011b, as L. periphragmoides).

Material examined - BRAZIL, Rio Grande do Sul, Porto Alegre, Baia do Cego, 08 May 1971, A. Schultz (ICN 6220); Viamão, 13 Jul 1965, F.R. Schoenwald (ICN 3722); ibid, 27 Jul 1965, F.R. Schoenwald (ICN 3780); ibid, 19 Nov 1965, F.R. Schoenwald (ICN 3787); São Leopoldo, 1907, J. Rick (PACA-FR 14818); ibid., 1905, J. Rick (PACA-FR 14819); ibid., 1930, J. Rick (PACA-FR 14820); ibid., 1933, J. Rick (PACA-FR 14821); ibid., 1946, Steffen (PACA-FR 20586); Porto Alegre, B. Braun (PACA-FR 14822).

Notes - The basidiome of this species is unique: a pseudostipe bearing a clathrate receptacle. Variation in color may occur, varying from pinkish, reddish to light orange. According to morphological and molecular data presented by Hernández Caffot et al. (2018), L. periphragmoides and $L$. sphaerocephalum are different species and should not be treated as synonyms.

\section{Phallaceae}

Itajahya galericulata Möller, Bot. Mitt. Trop. 7: 79, 148 (1895)

Fig. 2E

= Phallus fluminensis G.S. Medeiros, A.C.M. Rodrigues, R. Cruz \& Baseia, Stud. Fung. 2(1): 193 (2017), syn. nov.

Description - Möller (1895), Domínguez de Toledo (1995), Hernández Caffot et al. (2018).

Distribution in Southern Brazil - RS (Rick 1961), SC (Möller 1895). 
Material examined - BRAZIL, Rio Grande do Sul, Porto Alegre, under native bamboo (taquara), 06 Jun 1970, F.R. Schoenwald (ICN 6143); São Leopoldo, 1930, B. Braun (PACA-FR 19681).

Notes - the species is characterized by massive 'eggs' (3-8 cm high), a white pseudostipe, a hemispherical, wig-like receptacle with a flat apex that is covered with a calyptra (membranous cap). Braun (1932) reported the finding of a basidiome that reached $18 \mathrm{~cm}$ height when fully expanded. The species seems to be common in some localities of Southern Brazil and Argentina, but it was also reported from Bolivia and USA (Long \& Stouffer 1943). Itajahya rosea (Delile) E. Fisch., reported from Northeastern Brazil (Ottoni et al. 2010), is similar but has a pinkish pseudostipe.

Itajahya has been treated as a synonym of Phallus by some authors (e.g. Kreisel 1996, Calonge 2005, Ottoni et al. 2010), but recent molecular studies have shown evidence that it should be considered a distinct genus (Cabral et al. 2012). Here we consider P. fluminensis, a species recently described from Rio de Janeiro (Medeiros et al. 2017), synonymous with I. galericulata.

Mutinus argentinus Speg., An. Soc. Cient. Argent. 24: 62 (1887)

Fig. 2F

Description - Reid (1977), Maubet et al. (2018), Lima et al. (2019).

Distribution in Southern Brazil - PR (Meijer 2006, present study), SC (Möller 1895, present study).

Material examined - BRAZIL, Paraná, Fênix, Parque Estadual de Vila Rica do Espírito Santo, 23 Feb 1996, A.A.R. de Meijer 3290 (MBM); Santa Mariana, Fazenda Guaicurus, 01 Apr 1998, A.A.R. de Meijer 3561 (MBM); Céu Azul, Parque Nacional do Iguaçu, Trilha Manuel Gomes, 14 Dec 2010, L. Trierveiler-Pereira 154; Santa Catarina, Florianópolis, Trilha de Naufragados, 28 Oct 2012, S. Urrea-Valencia 178 (FLOR 48789).

Notes -The the species is characterized by a pinkish pseudostipe that tapers towards the apex, and a granulose, bright red fertile part with a small pore at the tip when mature. Spegazzini (1886) commented that $M$. argentinus is externally similar to the European M. caninus (Huds.) Fr., but its internal structure is more similar to M. bambusinus (Zoll.) E.Fisch., an Asian/African species.

Indeed, Mutinus argentinus and M. bambusinus have been treated as the same species by different authors (Kobayasi 1938, Cunningham 1944, Liu 1984). Dring \& Rose (1977) distinguished the two species, and presented illustrations of both. According to these authors, $M$. bambusinus has a pseudostipe with a marked sterile tip. The sterile tip of $M$. bambusinus was also illustrated by Petch (1926) and Demoulin \& Dring (1975). Mutinus mulleri Fisch., originally described from Brazil, is a synonym of M. argentinus (Kobayasi 1938, Reid 1977). It is possible that many records of $M$. bambusinus from the Neotropics actually correspond to M. argentinus (Reid 1977, Gube \& Piepenbring 2009). Möller (1895)'s photograph of M. bambusinus corresponds to M. argentinus.

Mutinus elegans (Mont.) E. Fisch. in Saccardo, Syll. Fung. 7: 13 (1888)

Fig. 2G

Description - Cortez et al. (2008).

Distribution in Southern Brazil - RS (Cortez et al. 2008).

Material examined - BRAZIL, Rio Grande do Sul, Parque Estadual de Itapuã, 22 May 2004, V.G. Cortez 16/04 (ICN 139004); Salvador do Sul [= São Salvador], 27 Mar 1944, J. Rick (PACAFR 22605, as M. bambusinus).

Notes - this species is characterized by the orange pseudostipe and not markedly defined fertile part, although the apex of the pseudostipe might be a little darker (dark orange to reddish). The pseudostipe shows the same surface texture all over it, while in M. argentinus the fertile part is rugulose. The species is known to occur in North America (supposed to be native there) and in Europe (introduced, according to Szczepcka 1995). Its first report from Brazil (Cortez et al. 2008) included a color photograph of a basidiome growing on sandy soil.

Phallus aureolatus Trierv.-Per. \& de Meijer, Phytotaxa 327(3): 229 (2017) $\quad$ Figs 3A, 4C 
Description - Trierveiler-Pereira et al. (2017)

Distribution in Southern Brazil - PR (Meijer 2006, as P. cf. merulinus; Trierveiler-Pereira et al. 2017) and SC (Trierveiler-Pereira et al. 2017).

Material examined - BRAZIL, Paraná, Antonina, Reserva Natural do Rio Cachoeira, 02 Feb 2005, A.A.R. de Meijer 4332 (MBM); Matinhos, 13 Nov 2010, J.M. Baltazar LTP109 (ICN); SANTA CATARINA, Florianópolis, UCAD, 23 Jan 2007, L. Trierveiler-Pereira (voucher not preserved; photograph presented by Trierveiler-Pereira et al. 2017).

Notes - The species is characterized by a pinkish volva, whitish pseudostipe, merulioid receptacle with a large pore at the apex (when fully mature) and long indusium with large meshes. Mycelial strands at the base of the volva are abundant and have violet pigments. The receptacle is usually surmounted by a narrow ring of white, sterile tissue, at first imperforate, and then perforate. The species is morphologically similar to P. merulinus (Berk.) Cooke, a species native from tropical Asia and Oceania and introduced in the Neotropics (Kreisel 1996, Cheype 2010), and P. atrovolvatus Kreisel \& Calonge, known from the Neotropics (Calonge et al. 2005, Cheype 2010), but both have a short and more delicate indusium with narrower meshes. Molecular data have shown that $P$. areolatus is phylogenetically distant from $P$. merulinus (Trierveiler-Pereira et al. 2017). The species is known from the State of Paraná and Santa Catarina, but we have seen photographs of specimens from the State of São Paulo (Fig. 4C), which might indicate that the species occurs throughout the Atlantic Forest.

Phallus callichrous (Möller) Lloyd, Mycol. Writ. 7: 6 (1907)

Description - Möller (1895), Lloyd (1907b).

Distribution in Southern Brazil - SC (Möller 1895), PR (Meijer 2006).

Material examined - BRAZIL, Paraná, Antonina, Reserva Natural do Rio Cachoeira, 14 Jan 2004, A.A.R. de Meijer 4307 (MBM).

Notes - The species is morphologically very similar to Phallus indusiatus, with the only difference that it has an orange receptacle (reason why we do not provide illustration of the species). According to Kreisel \& Hausknecht (2009), the receptacle color might also be pink. In the examined specimen, the indusium was white when fresh and became pale orange when dried (according to AARM). P. callichrous has been considered a synonym of $P$. indusiatus by some authors (Lloyd 1909, Calonge 2005, Cheype 2010), but here we follow Kreisel (1996) and Kreisel \& Hausknecht (2009), who have a rather narrow species concept. Phallus callichorus is known from tropical and subtropical Africa and Asia, Australia, and South America (Brazil) (Kreisel 1996).

Phallus campanulatus Berk., Ann. Mag. nat. Hist., Ser. 1 9: 446 (1842)

Fig. 3B

=Phallus granulosodenticulatus B. Braun, Relat. Gin. Anch. 1932: 12 (1932)

Description - Braun (1932), Cortez et al. (2011a), Trierveiler-Pereira et al. (2016).

Distribution in Southern Brazil - RS (Braun 1932, Cortez et al. 2011a - as P. granulosodenticulatus, Trierveiler-Pereira et al. 2016).

Material examined - BRAZIL, Rio Grande do Sul, São Leopoldo, 1929-1932, B. Braun (PACA-Fungi Rickiani 15042, 15043, 15044, 15045, 15046, 15048, 15050), ibid., Viamão, Estância Grande, 21 Jul 1965, F.R. Schoenwald (ICN 3736), ibid., Parque Estadual de Itapuã, on sand dunes, 18 Jun 2011, L. Trierveiler-Pereira 255 (ICN), ibid., on sandy soil with grass, 18 Jun 2011, L. TrierveilerPereira 256 (ICN), ibid., Santa Maria, UFSM, 16 Jun 2008, V.G. Cortez 117/08 (ICN 154390).

Notes - The species is characterized by a whitish pseudostipe with small perforations, an offwhite, perforate, narrow campanulate, wrinkled to minutely rugulose receptacle with a toothed margin. The pore at the receptacle apex is so prominent that a ring-like structure can be observed around it. The basidiospores are large, 4-6 × 2.5-3 $\mu \mathrm{m}$ (from LTP 255 and 256). Basidiome morphology is similar to $P$. aurantiacus Mont. and P. rubicundus (Bosc) Fr., except for the presence of orange and reddish pigments in these two species (Trierveiler-Pereira et al. 2016). 
Description - Cortez et al. (2011a), Coker \& Couch (1928), Smith (1951).

Distribution in Southern Brazil - RS (Cortez et al. 2011a).

Material examined - BRAZIL, Rio Grande do Sul, Viamão, Parque Estadual de Itapuã, 22 May 2004, V.G. Cortez 16/4 (ICN 154389); São Leopoldo, B. Braun (PACA-FR 15052).

Notes -The species is characterized by a whitish pseudostipe, reticulate receptacle and short indusium. Its morphology is very similar to $P$. indusiatus, except for the length of the indusium. According to Cortez et al. (2011a), the examined specimen had a yellowish white indusium, while specimens of $P$. duplicatus from the USA have a rosy pink indusium (Coker \& Couch 1928). $P$. indusiatus is common in the Neotropics, while $P$. duplicatus seems to be restricted to subtropical and temperate areas (Guzmán et al. 1990).

Phallus glutinolens (A. Möller) O. Kuntze emend. Trierveiler-Pereira, Calonge \& Baseia, Mycol. Progr. 8: 378 (2009)

Figs 3D, 4D

Description - Möller (1895), Trierveiler-Pereira et al. (2009a).

Distribution in Southern Brazil - RS (Braun 1932, Rick 1961), SC (Möller 1895, TrierveilerPereira et al. 2009a).

Material examined - BRAZIL, Rio Grande do Sul, São Leopoldo, 1931, Flach (PACA-FR 15041); Santa Catarina, Santo Amaro da Imperatriz, 12 May 2007, L. Trierveiler-Pereira (FLOR 77079, UFRN 834), Itapoá, Reserva Volta Velha, 18 Nov 2012, Urrea-Valencia 205 (FLOR 47632).

Notes - Phallus glutinolens has peculiar morphological features that differentiate it from all other Phallus species. The immature form ("egg") is depressed-globose and tuberculate, resembling immature forms of Clathrus species. The immature form has a membranous external layer with a light brown surface covered by small dark scales. This external layer is easily detached from the inner layer, which is yolk-yellow and has a viscid surface. When expanding from the egg, the receptacle is first depressed-globose to spherical. The glebal mass is not uniformly spread over the receptacle surface, but confined to juxtaposed irregular plates, which create the view of a cracked surface. Next, the receptacle becomes campanulate. The pseudostipe has elongated pores with a dilacerate margin, and in young specimens, it shows a ring marking the point where the receptacle had been connected to the immature pseudostipe. The spores are ellipsoid to cylindrical, 3.5-4.5 $\times$ 1.5-2 $\mu \mathrm{m}$, olive brown. Wright (1960) reported the species from Argentina and described the spores as much larger, viz. 5.1-6.9 $\mu \mathrm{m}$ long.

Phallus indusiatus Vent., Mém. Inst. Natl. Sci., Sci. Math. 1: 520 (1798)

Fig. 3E

Description - Guzmán et al. (1990), Baseia et al. (2006), Magnago et al. (2013).

Distribution in Southern Brazil - RS (Rick 1961), SC (Magnago et al. 2013), PR (Meijer 2006).

Material examined - BRAZIL, Rio Grande do Sul, São Leopoldo, 1905, J. Rick (PACA-FR 13139); ibid., B. Braun (PACA-FR 13519); Salvador do Sul [= São Salvador], 1945, J. Rick (PACA-FR 15040); Guaíba, Balneário Alvorada, Feb 1969, I.A. Mensch (ICN 5815); São Francisco de Paula, FLONA, 21 Apr 2007, V.G. Cortez 50/7 (ICN 154391); Dom Pedro de Alcântara, 11 Jun 2010, L. Trierveiler-Pereira 81 (ICN); ibid., 12 Jun 2010, L. Trierveiler-Pereira 85 (ICN); Porto Alegre, Campus do Vale, 11 Apr 2011, J.M. Baltazar LTP201 (ICN); Santa Catarina, Florianópolis, Campus da UFSC, 28 Feb 1985, C. Loguercio-Leite (FLOR 10072); ibid., Nov 2006, L. Trierveiler-Pereira (FLOR 31909); ibid., A.C. Magnago (FLOR); ibid., Capoeiras, 20 Mar 2013, L. Trierveiler-Pereira \& A.E. Pereira LTP311 (FLOR 48788); Paraná, Antonina, Reserva Natural do Rio Cachoeira, 02 Nov 2006, A.A.R. de Meijer 4348 (MBM).

Notes - The species is characterized by a whitish pseudostipe, a reticulate receptacle and the long indusium. Mycelial strands are often abundant and have purplish pigments. The species is very common in the Neotropics, but is also known from tropical and subtropical Africa and Asia, the Southern Pacific and Australia (Kreisel 1996). Phallus moelleri Lloyd (= Dictyophora phalloidea 
sensu A. Möller) is considered a synonym by many authors (e.g. Lloyd 1909, Guzmán et al. 1990, Calonge 2005), but Kreisel (1996) considers it distinct due to insertion of the indusium beneath the apex of the receptacle and the lack of pinkish/purplish pigments in volva and mycelial strands. We have not yet seen a specimen with such characteristics. Meijer (2010) reported from Diamante do Norte, in the northwestern tip of Paraná, a single collection (A.A.R. de Meijer 3364) of $P$. indusiatus var. roseus Lloyd. His material differs only from the type variety in the color of the indusium: pale orange instead of white (cf. Kreisel \& Hausknecht 2009).

Phallus rubicundus (Bosc) Fr., Syst. Mycol. 2, 284 (1823)

Fig. 3F

Description - Cortez \& Silva-Filho (2017).

Distribution in Southern Brazil - SC (present study), PR (Cortez \& Silva-Filho 2017).

Material examined - BRAZIL, Santa Catarina, Florianópolis, Ingleses, garden with lawn, 29 Jun 2013, T.B. Maccarini, MAN 1096 (FLOR 49587).

Notes - the species is characterized by the reddish to orange color of the pseudostipe and receptacle; lack of indusium and merulioid receptacle. It can be consufed with Mutinus, since the receptacle is thin and fragile, and sometimes remains attached to the pseudostipe. This is the first report of $P$. rubicundus from Santa Catarina.

Staheliomyces cinctus E. Fisch., Mitt. naturf. Ges. Bern: 142 (1921) [1920].

Figs $2 \mathrm{H}, 4 \mathrm{E}$

Description - Sáenz \& Nassar (1982), Baseia et al. (2006), Magnago et al. (2013).

Distribution in Southern Brazil - PR (present study).

Material examined - BRAZIL, Paraná, Antonina, Morro do Bom Brinquedo, 22 Jan 2008, T. Lockwood \& A.A.R. de Meijer 4388 (MBM); Guaraqueçaba, Tagaçaba Porto da Linha, 6 Feb 2009, D. Schause \& A.A.R. de Meijer 4425 (MBM).

Notes - this species, the only one described for the genus, is characterized by a white, perforate pseudostipe, with an annular constriction over which the glebal mass is spread. It is a common species in the Neotropics. One specimen kept at FLOR (10402) identified as Staheliomyces sp. corresponds to a Phallus species, probably P. campanulatus. This is the first report of $S$. cinctus from Southern Brazil.

\section{Protophallaceae}

Protubera maracuja Möller, Bot. Mitt. Trop. 7: 10, 145 (1895)

Fig. 2A

Description - Furtado \& Dring (1967), Trierveiler-Pereira et al. (2014a).

Distribution in Southern Brazil - RS (Rick 1961), SC (Möller 1895), PR (Meijer 2006, Trierveiler-Pereira et al. 2013, 2014a).

Material examined - BRAZIL, Rio Grande do Sul, Porto Alegre, Morro Santana, on decaying wood, 17 May 2011, L. Trierveiler-Pereira 219 (ICN); ibid., L. Trierveiler-Pereira 220 (ICN 168980); Santa Catarina, Florianópolis, Morro da Lagoa da Conceição, on soil, 10 May 1986, J. Furlani (FLOR 10312); ibid., on soil, 19 Dec 2011, M. Jaeger 94 (FLOR); ibid., on soil, 16 Feb 2012, M. Jaeger 133 (FLOR); Paraná, Curitiba, Parque Bariguí, on humus, 28 Aug 1996, A.A.R. de Meijer 3442 (MBM); Parque Barreirinha, on soil, 13 Mar 1992, A.A.R. de Meijer 2183 (MBM); Convento Solitude, on humus, 04 Mar 1995, A.A.R. de Meijer 3032 (MBM); Parque Regional do Iguaçu, on humus, 23 Apr 1995, A.A.R. de Meijer 3055 (MBM); Morretes, Parque Marumbi, on humus, 07 Sep 1997, A.A.R. de Meijer 3461 (MBM); ibid., on decaying wood, 11 Apr 1992, A.A.R. de Meijer 2237 (MBM); Guaraqueçaba, Tagaçaba Porto da Linha, on humus, 06 Aug 2009, D. Schause \& A.A.R. de Meijer 4466 (MBM); Reserva Natural Salto Morato, on decaying wood, 14 Dec 2011, L. Trierveiler-Pereira 284 (ICN).

Notes - The species is characterized by an epigeous, sequestrate habit; whitish to pale brown, grooved to smooth peridium and the presence of robust mycelial strands at the base. In transversal section are seen the elongated, olive to greenish brown glebal plates immersed in a gelatinous matrix. A columella is absent and the gelatinous layer is interrupted by sutures (sterile plates). 
Basidiomes can be found either on soil or on decaying wood. Protubera maracuja is separated from the other species of the genus by the combination of a pseudoparenchymatous outer peridium and the presence of large crystals forming rosette patterns on the inner peridium. Currently six species are accepted in the genus (Trierveiler-Pereira et al. 2014a) and P. maracuja is the only one reported from Brazil. Protubera jamaicensis (Murrill) Zeller, originally described from Jamaica, but also known from Costa Rica and Argentina (Trierveiler-Pereira et al. 2013, Wright 1960), is expected to occur in Brazil.

\section{Excluded species and doubtful records}

Aporophallus subtilis Möller, Bot. Mitt. Trop. 7: 68, 147 (1895)

Reported from - RS (Braun 1932, Rick 1929, 1961), SC (Möller 1895).

Notes $-A$. subtilis is a small and very curious phalloid. The only illustration of the species available in literature (Möller 1895, reproduced by Lloyd 1909) depicts a basidiome in longitudinal section. According to the original description, its pseudostipe is white and the apex is not perforated as other Phallus species. Herbarium material under this name at PACA (PACA-FR 15053) probably represents $P$. rubicundus. Aporophallus has been included in Phallus by some authors (e.g. Lloyd 1909, Kreisel 1996) and was considered a doubtful taxon by Calonge (2005). We prefer to keep this as a doubtful species, since no other material has been collected since its original description and examination of herbarium material is not conclusive.

Clathrus preussii Henn., Fungi camerun. 1: 108 (1897)

Reported from - RS (Rick 1961).

Notes $-C$. preussii is a rare African species characterized by a whitish receptaculum with short teeth surrounding the margins of the meshes (Dring 1964). One collection kept at PACA and labelled C. preussii was examined (São Leopoldo, 1930, J. Rick, PACA-FR 12628). It does not have the characteristic toothed margin and could correspond to C. chrysomycelinus or the whitish form of $C$. crispus. The species has been reported from Brazil only once, but we believe that it does not occur in the country, since most members of Clathrus are known to have a strong continental endemism (Dring 1980, Lécuru et al. 2013).

Clathrus pseudocrispus Lloyd, Mycol. Notes (Cincinnati) (3): 59 (1909)

Reported from - RS (Rick 1961).

Notes - According to Dring (1980), C. pseudocrispus is synonymous with C. crispus. Of three PACA collections at PACA, two seem to correspond to the whitish form of C. crispus (PACA-FR 12629 and 12622), and the other one, to the typical form (PACA-FR 12621).

Clathrus pusillus Berk., London J. Bot. 4: 67 (1845)

Reported from - RS (Rick 1961).

Notes - According to Lloyd (1909), the species was described from Australia and is characterized by a bright ruby receptacle with subequal meshes above, elongated meshes below, and wrinkled branches (Lloyd 1909). Dring (1980) treated the species as Colus pusillus (Berk.) Reichert, and reports it from the Australian continent only. An examined collection from PACA (São Leopoldo, B. Braun PACA-FR 19683) is badly damaged and it cannot be identified.

Lysurus borealis (Burt) Henn., Hedwigia 41(Beibl.): (172) (1902)

Reported from - RS (Rick 1961).

Notes - Six specimens of. L. borealis were mentioned by Rick (1961; PACA-FR 14015, 14002, 14018, 14019, 19691, 16692), but from all these we could find at PACA only one specimen, which corresponds to $L$. cruciatus. The synonymy of $L$. borealis with $L$. cruciatus was proposed by Dring (1980). 
Lysurus mokusin (L.) Fr., Syst. mycol. (Lundae) 2(2): 288 (1823)

Reported from - RS (Rick 1961).

Notes - The examined collections identified as L. mokusin contain small specimens of a Lysurus species (PACA-FR 14004, 14005, 14009). None of the specimens shows the main characteristic that defines L. mokusin: a pseudostipe with deeply grooved sides divided lengthwise by ribs. Other collection of L. mokusin reported by Rick (1961, PACA-FR 14010, 14011) were not found at PACA. Lysurus mokusin is common in Asia, Australia and USA (Dring 1980).

Lysurus sanctae-catharinae (E. Fisch.) Henn., Hedwigia 41(Beibl.): (172) (1902)

Reported from - RS (Rick 1961).

Notes - the examined material (São Leopoldo, 1929, J. Rick, PACA-FR 14017) corresponds to $L$. cruciatus. The synonym of $L$. sanctae-catharinae with $L$. cruciatus was already proposed by Dring (1980). The other collection reported by Rick (1961, PACA-FR 14001) was not found at PACA.

Lysurus woodii (MacOwan) Henn., Hedwigia 41(Beibl.): (172) (1902)

Reported from - RS (Rick 1961).

Notes - the examined material (São Leopoldo, B. Braun, PACA-FR 14008) corresponds to $L$. cruciatus var. nanus. Lysurus woodii was originally described from Africa and is characterized by small basidiomata (Van der Bijl 1921). The synonym of $L$. woodii with $L$. cruciatus was proposed by Dring (1980).

Mutinus bambusinus (Zoll.) E. Fisch., Ann. Jard. Bot. Buitenzorg 6: 30 (1886)

Reported from - RS (Rick 1961), SC (Möller 1895).

Notes - Mutinus bambusinus, originally described from Java, was distinguished from $M$. caninus by the spore-bearing portion of the pseudostipe being long and tapering, and reddish to dirty purplish (Fischer 1898-1899). It is possible that some of the records from Central and South America under this name actually correspond to M. argentinus (Gube \& Piepenbring 2009), a species described from Argentina by Spegazzini (1886) and also found in Southern Brazil (see above). Illustrations of both species were presented by Dring \& Rose (1977), and a color photo of M. bambusinus was presented by Demoulin \& Dring (1975). The photograph of M. bambusinus presented by Möller (1895) depicts $M$. argentinus. The examined collection at PACA (PACA-FR 22605) registered as $M$. bambusinus corresponds to M. elegans.

Mutinus borneensis Ces., Atti Accad. Sci. fis. mat. Napoli 8: 13 (1879)

Reported from - RS (Rick 1961), SC (Möller 1895).

Notes - the two collections at PACA cited by Rick (1961) are noted as Jansia boninensis (PACA-FR 13513, 13514). PACA-FR 13513 corresponds to Lysurus cruciatus, and PACA-FR 13514 corresponds to Phallus sp.

Mutinus rugulosus (E. Fisch.) Rick, Broteria, Sér. Biol. 21: 141 (1924)

Reported from - RS (Rick 1961).

Notes - Rick (1924) combined Phallus rugulosus Lloyd in Mutinus and stated: "habit similar to Phallus impudicus, but smaller and odor less strong; receptacle free and wrinkled" (our translation). It is difficult to understand why Rick transferred to Mutinus a species that he knew that had the receptacle separate from the pseudostipe. Later, Rick (1929) referred to M. rugulosus as this being a species similar to M. bambusinus but with a larger and whitish pseudostipe. It is therefore impossible to make a conclusion about Rick's concept of the species. The voucher specimen kept at PACA (PACA-FR 13512) is labeled as “Jansia rugosa?” and corresponds to a small Lysurus specimen. 

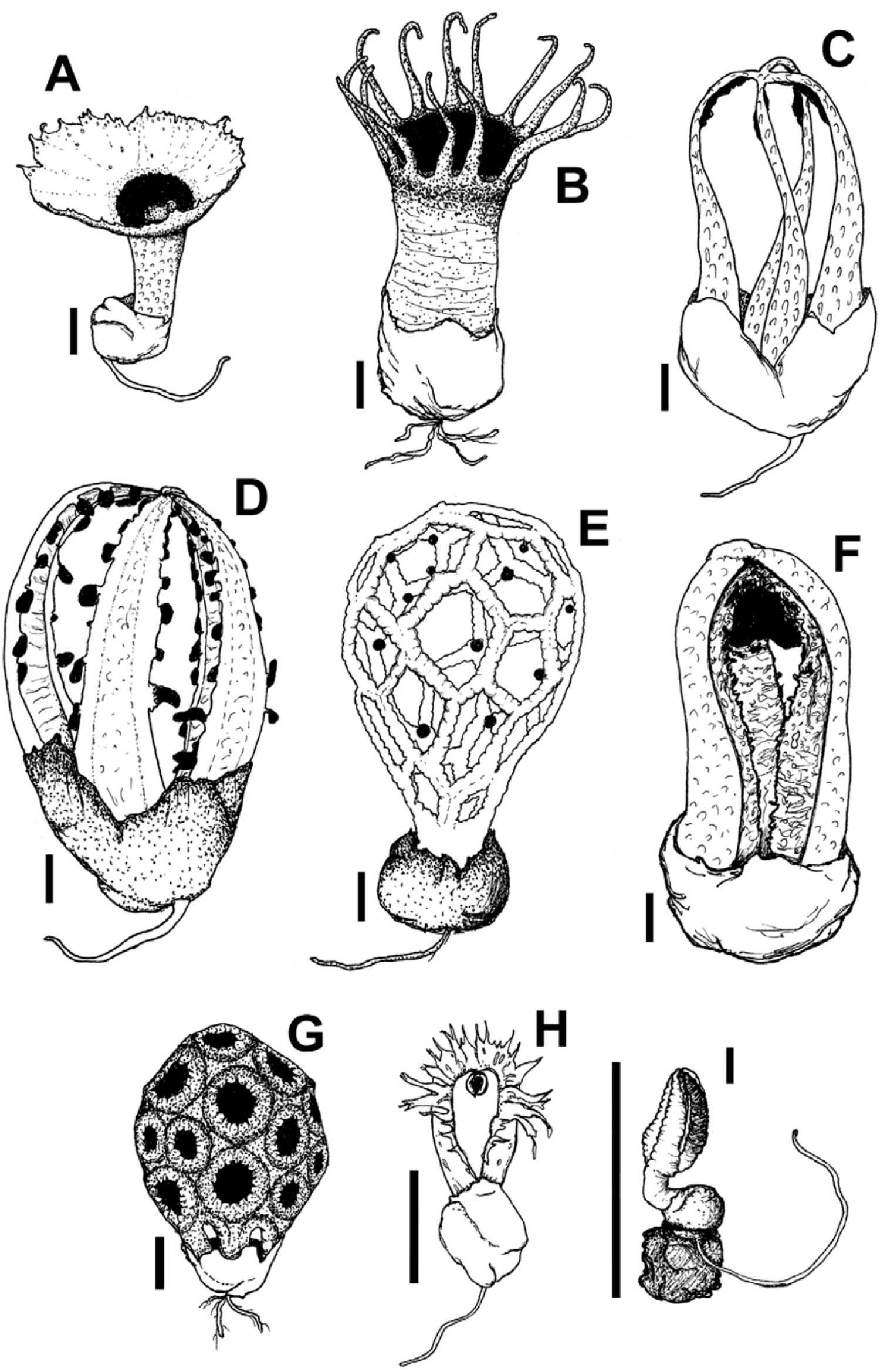

Fig. 1 - Clathraceae. A Abrachium floriforme. B Aseroë rubra. C Blumenavia angolensis. D B. rhacodes. E Clathrus chrysomycelinus. F C. columnatus. G C. crispus. H Laternea pusilla. I Pseudocolus garciae. Scale bars: $1 \mathrm{~cm}$. 

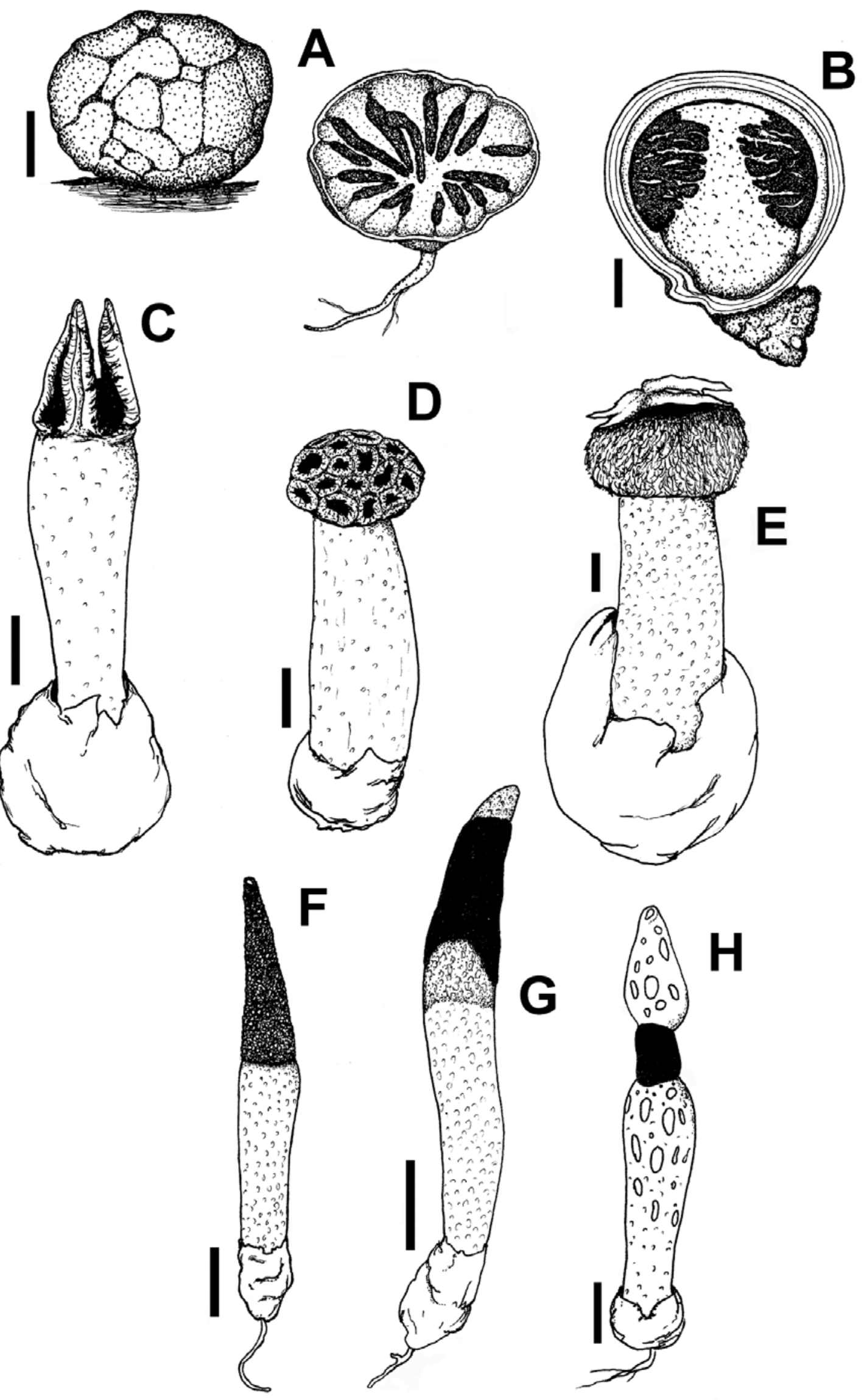

Fig. 2 - Protophallaceae, Claustulaceae, Lysuraceae and Phallaceae. A Protubera maracuja. B Gelopellis thaxteri. C Lysurus cruciatus. D L. sphaerocephalum. E Itajahya galericulata. F Mutinus argentinus. G M. elegans. H Staheliomyces cinctus. Scale bars: $1 \mathrm{~cm}$. 

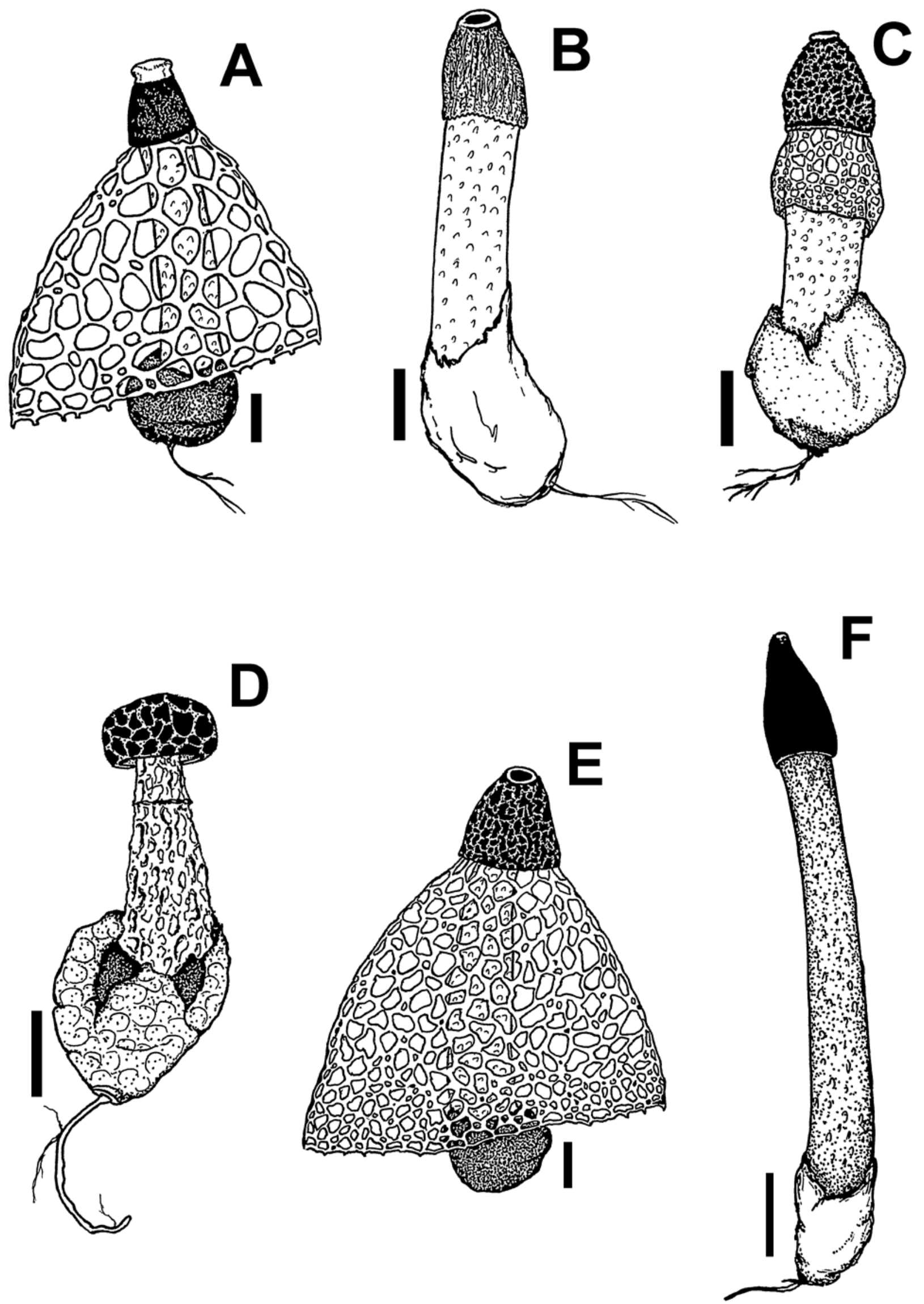

Fig. 3 - Phallaceae. A Phallus aureolatus. B P. campanulatus. C P. duplicatus. D Phallus glutinolens. E P. indusiatus. F P. rubicundus. Scale bars: $1 \mathrm{~cm}$. 

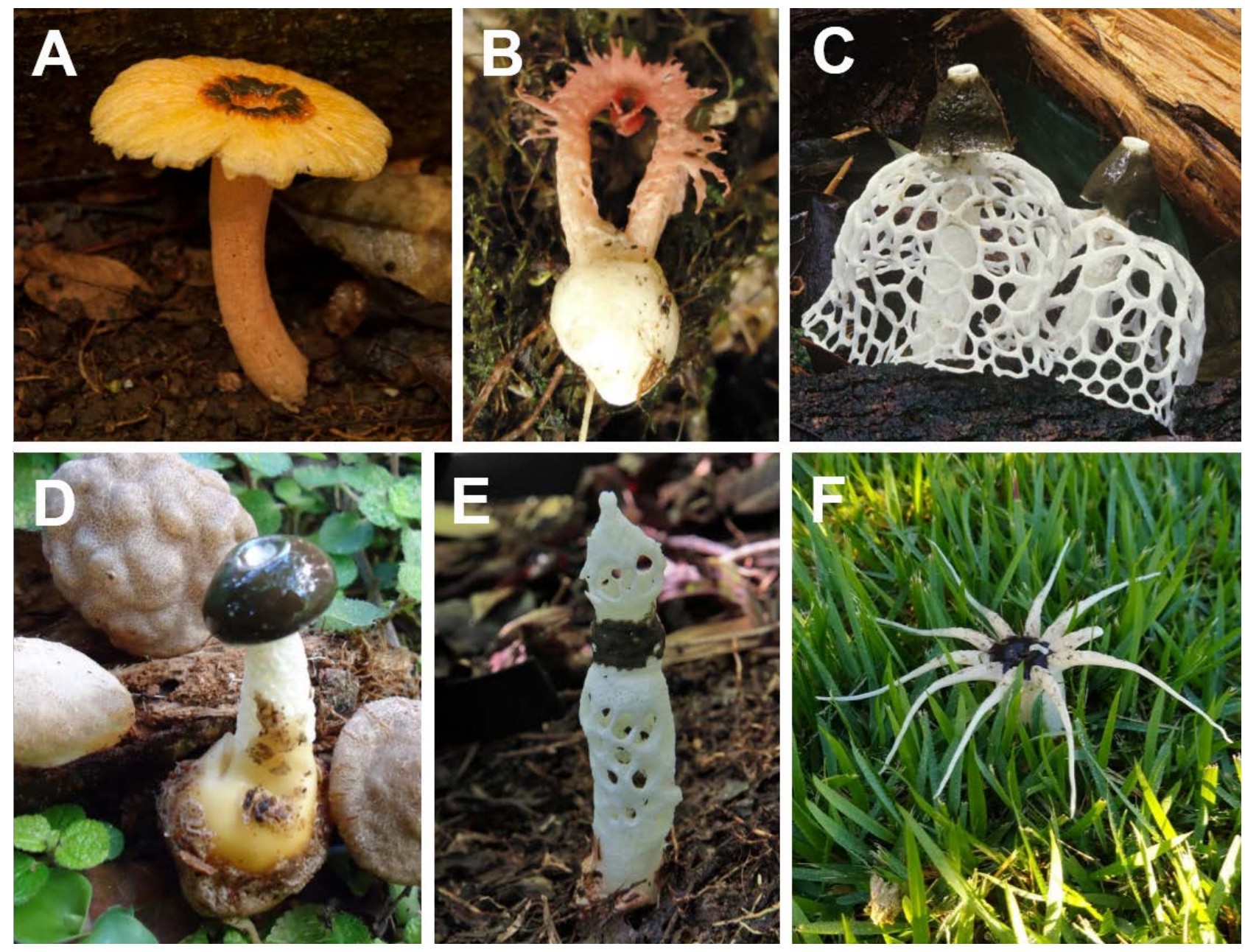

Fig. 4 - Phalloid basidiomes. A Abrachium floriforme from Santa Catarina (photo by Ariadne Furtado). B Laternea pusilla from Santa Catarina (photo by Celeste H. Cabrera). C Phallus aureolatus from São Paulo (photo by Fábio Colombini). D Phallus glutinolens from Santa Catarina (photo by Salomé Urrea Valencia). E Staheliomyces cinctus from Paraná (photo by Donald Schause). F Lysurus arachnoideus from Santa Catarina (photo by Jair Silveira Filho).

Laternea triscapa Turpin, Dict. Sci. Nat. 25: 248, 1822.

Reported from - RS (Rick 1961).

Notes - We couldn't find specimens of L. triscapa in Rick's collection at PACA and no voucher material is mentioned in his publication (Rick 1961). Judging the description presented by the author, the specimen could indeed be a Laternea species, since the gleba is described as separate from the receptacle and hanging from the apex. Laternea triscapa is known from the Neotropics, so it might occur in Southern Brazil, but no voucher specimen is available.

Pseudocolus rugulosus (Kurz) Lloyd, Synopsis of the known phalloids (7): 52 (1909)

Reported from - RS (Rick 1961).

Notes - The collection reported by Rick (1961, PACA-FR 14978) was not found at PACA. One specimen identified as Pseudocolus rugulosus (São Leopoldo, 1930, J. Rick, PACA-FR 21358) actually corresponds to Blumenavia rhacodes.

\section{Discussion}

To date, we accept the occurrence of 37 phalloid species in Brazil. Apart from those discussed here, we still can enumerate: Clathrus cristatus Fazolino, Calonge \& Baseia, C. natalensis G.S. Medeiros, Melanda, T.S. Cabral et al., Itajahya rosea (Delile) E. Fisch., Laternea dringii A. López, D. Martínez \& J. García, Lysurus arachnoideus (E. Fisch.) Trierv.-Per. \& K. 
Hosaka, Mutinus albotruncatus B.D.B. Silva \& Baseia, M. caninus (Huds.) Fr., M. fleischeri Penz., M. verrucossus T.S. Cabral, B.D.B. Silva, K. Hosaka et al., Phallus atrovolvatus Kreisel \& Calonge, P. cinnabarinus (W.S. Lee) Kreisel, P. merulinus (Berk.) Cooke, and Xylophallus xylogenus (Mont.) E. Fisch.

Phallus impudicus L., reported from the State of São Paulo (Averna-Saccá 1923), we prefer to concern a misidentification, as it is basically a temperate species (Kreisel 1996) and no voucher is available. The genus Ileodictyon is apparently absent from the country and the single record from Northeastern Brazil (Baseia et al. 2006) corresponds to C. chrysomycelinus. The occurrence in Brazil of the Neotropical Laternea triscapa still needs confirmation; in Southern Brazil no specimens were found in the field or in the herbaria, and the collection described from Northeastern Brazil (Baseia et al. 2006) seems to concern L. dringii, due to its basidiome color, size and habitat.

Floccomutinus sp., reported by Wright (1960) from Bolivia (Cerro Uchumachi, circa $16^{\circ} \mathrm{S}$ latitude), probably corresponds to $X$. xylogenus. If so, it is likely that the species also occurs in the Central-Western region from Brazil. Laternea pusilla, which in this study is described for the first time from Brazil, may occur in cloud forests all over subtropical-tropical Brazil.

We believe that still more phalloid species will be discovered in southern Brazil. Further studies in this group - providing good descriptions and illustrations or photographs - will eventually throw a better light on the pattern of species distribution in the Neotropics.

\section{Acknowledgements}

The first author would like to thank friends for supplying specimens and all colleagues that helped during the field work. Ariadne Furtado, Celeste H. Cabrera, Donald Schause, Fabio Colombini, Jair Silveira Filho, and Salomé Urrea Valencia are acknowledged for supplying beautiful photographs of phalloid specimens. We also thank the direction of the surveyed areas for allowances to collect. This study is a partial result of the first author's Ph.D. thesis, with a scholarship provided by the Brazilian government (CAPES).

\section{References}

Averna-Saccá R. 1923 - Os gasteromycetes mais comuns nas hortas, nos pomares e nos campos. Boletim de Agricultura (São Paulo) 23(9-10), 306-318.

Baseia IG, Gibertoni TB, Maia LC. 2003 - Phallus pygmaeus, a new minute species from a Brazilian tropical rainforest. Mycotaxon 85, 77-79.

Baseia IG, Calonge FD. 2005 - Aseroë floriformis, a new phalloid with a sunflower-shaped receptacle. Mycotaxon 92, 169-172.

Baseia IG, Calonge FD, Maia LC. 2006 - Notes on the Phallales in the Neotropics. Boletín de la Sociedad Micológica de Madrid 30, 87-93.

Braun B. 1932 - Estudo sobre as phalloideas riograndenses. Relatório do Ginásio Anchieta (Porto Alegre) 1932, 5-28.

Bononi VLR, Guzmán G, Capelari M. 1984 - Basidiomicetos do Parque Estadual da Ilha do Cardoso V: Gasteromicetos. Rickia 11, 91-97.

Cabral TS, Marinho P, Goto BT, Baseia IG. 2012 - Abrachium, a new genus in the Clathraceae, and Itajahya reassessed. Mycotaxon 119, 419-429.

Cabral TS, Silva BDB, Ishikawa NK, Alfredo DS et al. 2014 - A new species and new records of gasteroid fungi (Basidiomycota) from Central Amazonia, Brazil. Phytotaxa 183 (4), 239-253.

Cabral TS, Clement CR, Baseia IG. 2015 - Amazonian phalloids: new records from Brazil and South America. Mycotaxon 130. 315-320.

Calonge FD. 2005 - A tentative key to identify the species of Phallus. Boletín de la Sociedad Micológica de Madrid 29, 9-17.

Calonge FD, Guzmán G, F. Ramírez-Guillén F, Gándara E. 2007 - Adiciones al catálogo de Gasteromycetes de México, con referencia especial a los géneros Blumenavia y Tulostoma. Boletín de la Sociedad Micológica de Madrid 31, 151-155. 
Calonge FD, Kreisel H, Mata M. 2005 - Phallus atrovolvatus, a new species from Costa Rica. Boletín de la Sociedad Micológica de Madrid 29, 5-8.

Cheype JL. 2010 - Phallaceae et Clathrus récoltés en Guyane Française. Bulletin Mycologique et Botanique Dauphiné-Savoie 197, 51-66.

Coker WE, Couch JN. 1928 - The Gasteromycetes of the eastern United States and Canada. North Carolina Press, Chapel Hill.

Cortez VG, Baseia IG, Silveira RMB. 2008 - Gasteromicetos (Basidiomycota) no Parque Estadual de Itapuã, Viamão, Rio Grande do Sul, Brasil. Revista Brasileira de Biociências (Porto Alegre) 6(3), 291-299.

Cortez VG, Baseia IG, Silveira RMB. 2011a - Two noteworthy Phallus from southern Brazil. Mycoscience 52, 436-438.

Cortez VG, Baseia IG, Silveira RMB. 2011b - Gasteroid mycobiota of Rio Grande do Sul, Brazil: Lysuraceae (Basidiomycota). Acta Scientiarum. Biological Sciences 33, 87-92.

Cortez VG, Silva-Filho AGS. 2017 - Phallus rubicundus in South Brazil. Studies in Fungi 2(1), 59-63.

Crous PW, Wingfield MJ, Burgess TI, Carnegie AJ et al. 2017 - Fungal Planet description sheets: 625-715. Persoonia 39, 270-467.

Crous PW, Luangsa-ard JJ, Wingfield MJ, Carnegie AJ et al. 2018 - Fungal Planet description sheets: 785-867. Persoonia 41, 238-417.

Cunningham GH. 1931 - The Gasteromycetes of Australasia X. The Phallales, Part I. Proceedings of the Linnean Society of New South Wales 56, 1-15.

Cunningham GH. 1944 - The Gasteromycetes of Australia and New Zealand. McIndoe, Dunedin.

Degreef J, Amalfi M, Decock C, Demoulin V. 2013 - Two rare Phallales recorded from São Tomé. Cryptogamie, Mycologie 34(1), 3-13.

Demoulin V, Dring DM. 1975 - Gasteromycetes of Kivu (Zaire), Rwanda and Burundi. Bulletin du Jardin Botanique National de Belgique 45, 339-372.

Dennis RWG. 1970 - Fungus flora of Venezuela and adjacent countries. Kew Bulletin Additional Series 3, 181-235.

Dissing H, Lange M. 1963 - Gasteromycetales I. Flore iconographique des champignons du Congo 12, 215-232.

Domínguez de Toledo LS. 1985 - Una nueva especie de Clathrus (Eumycota, Phallales). Boletín de la Sociedad Argentina de Botánica 24(1-2), 131-136.

Domínguez de Toledo LS. 1995 - Gasteromycetes (Eumycota) del centro y oeste de la Argentina. II. Orden Phallales. Darwiniana 33(1-4), 195-210.

Dring DM. 1964 - Gasteromycetes of West Tropical Africa. Mycological Paper 98, 1-60.

Dring DM. 1980 - Contributions towards a rational arrangement of the Clathraceae. Kew Bulletin 35, 1-96.

Dring DM, Rose AC. 1977 - Additions to West African phalloid fungi. Kew Bulletin 31(3): 741751.

Furtado JD, Dring DM. 1967 - The rediscovery of Protubera maracuja with additional descriptive notes. Transactions of the British Mycological Society 50, 500-502.

Fazolino EP, Trierveiler-Pereira L, Calonge FD, Baseia IG. 2010 - First records of Clathrus (Phallaceae, Agaricomycetes) from the Northeast Region of Brazil. Mycotaxon 113, 195-202.

Fischer E. 1898-1899 - Phallineae. In: Engler A, Prantl K (eds), Die natürlichen Pflanzenfamilien, Teil 1, Abteilung 1**. Leipzig, W. Engelmann, pp. 276-296.

Fischer E. 1933 - Gasteromyceteae Stahelianae. Annales Mycologici 31(3), 113-125.

Gómez LD, Gazis R. 2006 - Dos Gasteromycetes (Basidiomycotina, Fungi) del Perú. Brenesia 65, 71.

Gube M, Piepenbring M. 2009 - Preliminary annotated checklist of Gasteromycetes in Panama. Nova Hedwigia 89(3-4), 519-543.

Guerrero, RT, Homrich MH. 1999 - Fungos macroscópicos comuns no Rio Grande do Sul. Guia para identificação. $2^{a}$ Ed. Editora Universidade/UFRGS, Porto Alegre. 
Guzmán G, Montoya L, Bandala VM. 1990 - Las especies y formas de Dictyophora (Fungi, Basidiomycetes, Phallales) en México y observaciones sobre su distribución en América Latina. Acta Botánica Mexicana 9, 1-11.

Hernández Caffot ML, Robledo G, Domínguez LS. 2013 - Gasteroid mycobiota (Basidiomycota) from Polylepis australis woodlands of central Argentina. http://www.mycotaxon.com/ resources/weblists.html (accessed in 14 April 2019).

Hernández Caffot ML, Hosaka K, Domínguez LS, Urcelay C. 2018 - Molecular and morphological data validate the new combination of Lysurus sphaerocephalum from Argentina, with some additional records on Phallales (Agaricomycetes). Mycologia 110(2), 419-433.

Homrich MH. 1969 - Etude de quelques Gasteromycetes du Rio Grande do Sul. Revue de Mycologie (Paris) 34(1), 3-16.

Hosaka K, Bates ST, Beever RE, Castellano ME. 2006 - Molecular phylogenetics of the gomphoid-phalloid fungi with an establishment of the new subclass Phallomycetidae and two new orders. Mycologia 98, 949-959.

Kirk PM, Cannon PF, Minter DW, Stalpers JA. 2008 - Dictionary of the fungi. 10th Ed. CAB International, Wallingford.

Kobayasi Y. 1938 - Hymenogastrineae et Phallineae. In: Nakai T, Honda M (eds.), Nova Flora Japonica. Sanseido, Tokyo and Osaka.

Kornerup A, Wanscher JH. 1978 - Methuen Handbook of Colour. 3rd Edn. Eyre Methuen, London.

Kreisel H. 1996 - A preliminary survey of the genus Phallus sensu lato. Czech Mycology 48(4), 273-281.

Kreisel H, Hausknecht A. 2009 - The gasteral basidiomycetes of Mascarenes and Seychelles 3. Some recent records. Österreichische Zeitschrift für Pilzkunde 18, 149-159.

Lazo W. 2001 - Hongos de Chile, Atlas Micológico. Facultad de Ciencias de la Universidad de Chile, Santiago.

Lécuru C, Mornand J, Fiard JP, Moreau PA, Courtecuisse R. 2013 - Clathrus roseovolvatus, a new phalloid fungus from the Caribbean. Cryptogamie Mycologie 34(1), 35-44.

Lima AA, Gurgel RAF, Oliveira RL, Ferreira RJ et al. 2019 - New records of Phallales (Basidiomycota) from Brazilian semi-arid region. Current Research in Environmental \& Applied Mycology 9(1), 15-24.

Liu B. 1984 - The Gasteromycetes of China. Beihefte zur Nova Hedwigia 74, 1-235.

Lloyd CG. 1909 - Synopsis of the known phalloids. Mycological Writings 3, 1-96.

Lloyd CG. 1907a - Mycological Notes no. 26. Concerning the phalloids. Mycological Writings 2: 325-337.

Lloyd CG. 1907b - The phalloids of Australasia. Mycological Writings 2: 1-24.

Long WH, Stouffer DJ. 1943 - Studies in the Gasteromycetes - IX. The genus Itajahya in North America. Mycologia 35(6), 620-628.

López A, Martínez L, García J. 1981 - Adiciones al conocimiento de los Phallales del estado de Veracruz. Boletin de la Sociedad Mexicana de Micología 16, 109-116.

López A, García J, Martínez L. 1982 - Primer registro de Laternea pusilla Berk. \& Curt. y L. triscapa Turp. (Basidiomycetes, Clathraceae) en Mexico. Boletin de la Sociedad Mexicana de Micología 17, 71-75.

Magnago AC, Trierveiler-Pereira L, Neves MA. 2013 - Phallales (Agaricomycetes, Fungi) from the tropical Atlantic Forest of Brazil. Bulletin of the Torrey Botanical Club 140(2), 236-244.

Martín MP, Calonge FD, Marcos B. 2005 - The limits between Lysurus cruciatus and L. cruciatus var. nanus: a comparative DNA sequential study. Boletín de la Sociedad Micológica de Madrid 29, 31-35.

Maubet Y, Campi M, Trierveiler-Pereira L, Moreno G. 2018 - Contribución a la micota gasteroide de Paraguay. Nuevas citas. Boletín de la Sociedad Micológica de Madrid 42, 115-124.

Meijer AAR. 2006 - Preliminary list of the macromycetes from the Brazilian State of Paraná. Boletim do Museu Botanico Municipal (Curitiba) 68, 1-55. 
Meijer AAR. 2010 - Preliminary list of the macromycetes from the Brazilian state of Paraná: corrections and updating. Boletim do Museu Botanico Municipal (Curitiba) 72: 1-9.

Miller Jr. OK, Miller HH. 1988 - Gasteromycetes: morphology and developmental features. Mad River, Eureka.

Möller A. 1895 - Brasilische Pilzblumen. Botanische Mitteilungen aus den Tropen 7, 1-152.

Ottoni T, Silva BDB, Silva EP, Fazolino EP, Baseia IG. 2010 - Phallus roseus, first record from the neotropics. Mycotaxon 112, 5-8.

Petch T. 1926 - Mutinus bambusinus (Zoll.) Fischer. Transactions of the British Mycological Society 10, 272-282.

Reid DA. 1977 - Some Gasteromycetes from Trinidad and Tobago. Kew Bulletin 31(3), 657-690.

Rick J. 1906 - Pilze aus Rio Grande do Sul. Broteria 5, 5-53.

Rick J. 1924 - Fungi gelatinosi et cartilaginosi Rio-Grandenses. Broteria 21, 134-141.

Rick J. 1929 - Phalloideas riograndenses. Egatea 14, 299-305

Rick J. 1961 - Basidiomycetes Eubasidii in Rio Grande do Sul-Brasilia 6. Iheringia Série Botanica 9, 451-479.

Sáenz JA. 1975 - Ecology, anatomy and redescription of Laternea pusilla. Revista de Biología Tropical 24(1), 109-121.

Sáenz JA. 1980 - Ligiella, a new genus for the Clathraceae. Mycologia 72, 338-349.

Sáenz JA, Nassar M. 1982 - Hongos de Costa Rica: familias Phallaceae y Clathraceae. Revista de Biología Tropical 30(1), 41-52.

Sandoval-Leiva P, Henríquez JL, Trierveiler-Pereira L. 2014 - Additions to the Chilean phalloid mycota. Mycotaxon 128, 45-54.

Silva BDB, Cabral TS, Martín MP, Marinho P et al. 2015 - Mutinus albotruncatus (Phallales, Agaricomycetes), a new phalloid from the Brazilian semiarid, and a key to the world species. Phytotaxa 236(3), 237-248.

Smith AH. 1951 - Puffballs and their allies in Michigan. University of Michigan Press, Ann Arbor.

Sobestiansky G. 2005 - Contribution to a macromycete survey of the states of Rio Grande do Sul and Santa Catarina in Brazil. Brazilian Archives of Biology and Technology 48: 437-457.

Spegazzini C. 1886[1887] - Las faloideas argentinas. Anales de la Sociedad Científica de Argentina 24, 59-68.

Sulzbacher MA, Cortez VG, Baseia IG. 2013 - Rediscovery of Pseudocolus garciae in southern Brazil. Mycotaxon 123, 113-119.

Szczepcka M.Z. 1995 - Clé de détermination des especes europeennes du genre Mutinus Fr. Documents Mycologiques 25(98-100), 453-458.

Thiers B. 2011 [continuously updated] - Index Herbariorum: a global directory of public herbaria and associated staff. New York Botanical Garden's Virtual Herbarium. http:// sweetgum.nybg.org/ih/ (accessed 14 April 2019).

Trierveiler-Pereira L. 2015 - Phalloid fungi (Phallales) of Brazil. Field Guides, The Field Museum. https://fieldguides.fieldmuseum.org/guides/guide/716 (accessed 14 April 2019).

Trierveiler-Pereira L, Loguercio-Leite C, Calonge FD, Baseia IG - 2009a. An emendation of Phallus glutinolens. Mycological Progress 8, 377-380.

Trierveiler-Pereira L, Gomes-Silva AC, Baseia IG - 2009b. Notes on gasteroid fungi of the Brazilian Amazon rainforest. Mycotaxon 110, 73-80.

Trierveiler-Pereira L, Baseia IG. 2011 - Contribution to the knowledge of gasteroid fungi (Agaricomycetes, Basidiomycota) from the state of Paraíba, Brazil. Revista Brasileira de Biociências (Porto Alegre) 9(2), 167-173.

Trierveiler-Pereira L, Silveira RMB. 2012 - Notes on Xylophallus xylogenus (Phallaceae, Agaricomycetes) based on Brazilian specimens. Mycotaxon 120: 309-316.

Trierveiler-Pereira L, Wilson AW, Silveira RMB, Domínguez LS. 2013 - Costa Rican gasteromycetes (Basidiomycota, Fungi): Calostomataceae, Phallaceae and Protophallaceae. Nova Hedwigia 96(3-4), 533-544. 
Trierveiler-Pereira L, de Meijer AAR, Hosaka K, Silveira RMB. 2014a - Updates on Protubera (Protophallaceae, Phallales) and additional notes on P. maracuja. Mycoscience 55, 35-42.

Trierveiler-Pereira L, Silveira RMB, Hosaka K. 2014b - Multigene phylogeny of the Phallales (Phallomycetidae, Agaricomycetes) focusing on some previously unrepresented genera. Mycologia 106(5), 904-911.

Trierveiler-Pereira L, Alves CR, Silveira RMB. 2014c - The genus Blumenavia (Clathraceae, Phallales). Mycosphere 5(3), 496-501.

Trierveiler-Pereira L, de Meijer AAR, Reck MA, Hosaka K, Silveira RMB. 2017 - Phallus aureolatus (Phallaceae, Agaricomycetes), a new species from the Brazilian Atlantic Forest. Phytotaxa 327(3), 223-236.

Trierveiler-Pereira L, Baltazar JM, Silveira RM. 2016 - Phallus campanulatus Berk. (Phallaceae, Agaricomycetes), a poorly known species from South America and its synonym $P$. granulosodenticulatus B. Braun. Phytotaxa 286(2), 127-130.

Trierveiler-Pereira L, Honaiser LP, Silveira RMB. 2018 - Diversity of gasteroid fungi (Agaricomycetes, Basidiomycota) from the Brazilian Pampa Biome. Nova Hedwigia 106(34), 305-324.

Van der Bijl PA. 1921 - Note on Lysurus woodii (MacOwan) Lloyd. Transactions of the Royal Society of South Africa 9, 191-193.

Wright JE. 1949 - Los “Gasteromycetes” del Museo Argentino de Ciencias Naturales "Bernardino Rivadavia”. I. Phallales. Comunicaciones del Instituto Nacional de Investigaciones de las Ciencias Naturales 1(2), 3-15.

Wright JE. 1960 - Notas sobre Faloideas Sud y Centroamericanas. Lilloa 30, 339-359.

Zeller SM. 1939 - New and noteworthy Gasteromycetes. Mycologia 31, 1-32.

Zeller SM, Dodge CW. 1929 - Hysterangium in North America. Annals of the Missouri Botanical Garden 16, 83-128. 